\title{
The Effect of Entrepreneurial Orientation, Market Orientation, Business Network Ability and Product Innovation on Performance (Study in Small and Micro Enterprises of Food in Padang)
}

\author{
Najmi Najmi ${ }^{1}$, Abror Abror ${ }^{2 *}$ \\ 1Universitas Negeri Padang, Padang, Indonesia, $₫$ najmi27081994@gmail.com \\ 2Universitas Negeri Padang, Padang, Indonesia, \abror094@gmail.com; abror094@fe.unp.ac.id \\ ${ }^{*}$ Corresponding Author
}

\begin{abstract}
This study aims to analyze the effect of Entrepreneurial Orientation on Market Orientation, Entrepreneurial Orientation on Business network ability, Entrepreneurial Orientation on Product Innovation, Market Orientation on Product Innovation, Market Orientation on performance, Business network ability on Product Innovation, Product Innovation on Performance. Research objects are Small and micro Enterprises of Food in Padang City. The sample in this study were 195 respondents. Sampling techniques is Purposive sampling. Data analysis is SEM (Structural Equation Model) with PLS 3 program. The results of this study show that Entrepreneurial orientation has a positive effect on market orientation, Entrepreneurial orientation has a positive effect on Business network ability, Entrepreneurial orientation has a positive effect on product innovation, Market orientation has not effect on product innovation, market orientation has a positive effect on performance, Business network ability has not effect on product innovation, Product innovation has a positive effect on performance.
\end{abstract}

Keywords: entrepreneurial orientation, market orientation, business network ability, product innovation, performance.

\section{Introduction}

Small and micro enterprises sector has a strategic role in the growth and development of the national economy. This sector is able to prove its existence in the economy of Indonesia. When the monetary crisis hit Indonesia in 1998, this sector was able to survive compared to the large businesses. small and micro enterprises showed its ability to survive at situation that caused many of the big businesses to go bankrupt. Because most of small and micro sector is not too dependent on large capital or foreign currency loans. So, when there are fluctuations in exchange rates, large scale businesses that generally always deal with foreign currencies, so that the most potential to experience the impact of the crisis. The economic crisis in 1998 illustrates that small and micro enterprises play a major role in developing community welfare, growth and economic development in Indonesia (Nur \& Salim, 2014).

Small and micro enterprises are productive business opportunities which are established by individuals or business entities that are not business branches that are owned, controlled, or become part of either directly or indirectly from medium sized businesses or large businesses that meet the criteria of small and micro enterprises. The criteria for micro entreprises in the provisions of the Law of the Republic of Indonesia No. 20 of 2008 is a business that have annual sales of at most Rp. $300,000,000.00$ (three hundred million rupiah). While small enterprises have annual sales of more than IDR. 300,000,000.00 (three hundred million rupiahs) up to a maximum of IDR. 2,500,000,000.00 (two billion five hundred million rupiah).

Small and Micro enterprises of food is the one of the most enterprises in Padang city, where food enterprises are all forms of food products produced by the community themselves or a business carried out through processing raw materials or semi finished goods into finished goods which has added value to gain profit. For examples are various of cakes, breads and cracks. Potato stick, Fried foods, Fried noodles, Sandwich, shredded food, Tofu nuggets, Pastry, etc. 
Based on preliminary observations on small and micro entrepreneurs, it was found that the ability of small and micro entrepreneurs to innovate in the products produced was low. This can be seen from the variety of flavors of food products that are not developed, variations in food products are monotonous, and the quality of food products are less than competitor. Furthermore, the ability to develop superior products are still lacking. Next, the problem that occurs is the lack to see information about superior competitor products, so small and micro entrepreneurs less to creat new products to make their product more interest. This cause customers of small and micro enterprises decreased because some customers choose products produced by medium sized businesses or large businesses.

The next problem related on entrepreneurial orientation. Based on preliminary observations, it was found that small and micro enterprises of food also lack of courage to take a risk, such as developing their business production so the marketing of their products reaches regional or national scale. Most of small and micro Entrepreneurs have not to develop their business such as opening a branch. lack of having a proactive attitude to identify business opportunities. This causes small and micro entreprises products are not develop. the next problem related market orientation. In preliminary observations, it was found that a number of food entrepreneurs in padang city were still low in uses a market orientation strategy. This can be seen from low capacity of small and micro enterprises of food in collecting and analyzing information related to the needs and desires of customer. Most of entrepreneur claim that the business they established is more about the motive of participating without looking information about customer needs. In addition, most of entrepreneurs less information about competitor strategies to do business activity like, competitors that are very competitive in marketing or their products. This causes the lack of literacy of entrepreneurs to know how the best marketing strategies to market their product, The next problem is less ability to choose right strategy to anticipate competitor actions, so small and micro enterprises can not maintain their business continuity or improve their business performance.

The next problem related how to build partners or networks. Small and micro enterprises of food have weak ability to build partners or networks. They do not establish partnerships with large entrepreneurs. Even though, if they establish partnerships, so it can avoid the occurrence of monopoly in business. The weak business network ability causes business actors can not expand market share and manage business efficiently, so business actors have not the strength to compete with other business actors, both in the same type of business, medium sized businesses or large businesses.

Small and micro enterprises of Food is one of the most business in Padang City. Most of this business has increased competition among entrepreneurs. there are various problems experienced by entrepreneurs, such as have not ability to increase their income until they cannot maintain their business continuity. The next problems are the ability of an entrepreneur still low in product innovation, limited access to market information, lack of knowledge about access to capital, lack of ability to establish networks and partnerships, efforts to maintain business existence and market their products on a local scale, rather than developing businesses towards regional and international scales. Some of the above issues have an impact on the small and micro performance, namely the inability of businesses to improve their business performance. This problem can be seen from the percentage of growth sale.

Table 1 Small and micro Enterprises Performance of Food in Padang City

\begin{tabular}{cccc}
\hline years & $\begin{array}{c}\text { Number } \\
\text { of units }\end{array}$ & Sales & $\begin{array}{c}\text { Percentage of sale } \\
\text { growth (\%) }\end{array}$ \\
\hline 2013 & 400 & 4.205 .398 .250 & - \\
\hline 2014 & 430 & 4.498 .450 .670 & 6.96 \\
\hline 2015 & 412 & 3.899 .250 .325 & 9.5 \\
\hline 2016 & 390 & 3.445 .230 .576 & 6.65 \\
\hline 2017 & 370 & 3.138 .459 .398 & 3.98 \\
\hline
\end{tabular}

Source: Office of cooperative and micro, small and medium enterprises in Padang City 
Based on table 1, it can be seen that the number of small and micro food processing in fluctuates every year. It was seen in 2013 the number of small and micro food processing many as 400 units. This number has increase in 2014 with a total of 430 units. Then, there was a decline back in 2015 to 412 units and declined in 2016 to 390 units and continued to decline in 2017 to 370 units. The increase and decrease in the number of micro and small food processing in the city of Padang is also accompanied by a decrease in the performance of these businesses, we can see from the percentage growth in sales volume which tends to decrease every year. As in 2014 the sales volume of food processing small and micro enterprises in Padang City grew by 6.96\%. then, increased in 2015, which was $9.5 \%$. In 2016 it declined to $6.65 \%$ and continued to decline in 2017 to $3.98 \%$.

Based on the problem of small and micro food processing in Padang city, the inability of a business to improve its performance is thought to be influenced by several factors, namely the inability of small and micro food processing to carry out market orientation strategies and the sector's lack of product innovation. Then, the problem relate product innovation can caused by lack of entrepreneurial orientation, market orientation and business network ability.

According to Solano, et. al., (2018) market orientation and business network ability are factors that can improve performance. Then, Rhee, et. al., (2010) also revealed that various strategy orientations not only effect the performance of small and micro enterprises, it will enhance product innovation. Entrepreneurial orientation and market orientation can improve product innovation. Then, collaboration with partners can improve product innovation in small and medium enterprises (Qiao, 2014). Rhee, et. al., (2010) uses two indicators for entrepreneurial orientation, namely risk taking and proactive. Proactive is the ability of businesses to take advantage of business opportunities. Furthermore, risk taking involves the act of daring to take a project that has a higher failure rate. Rhee, et. al., (2010) uses two indicators to measure market orientation, namely customer orientation and competitor orientation. Customer orientation is an understanding of customer needs. Competitor orientation is the desire of the business actor to respond quickly to the actions of competitors. Solano, et. al., (2018) uses four dimensions to measure business network capabilities, namely: Coordination, Skills of relations, Knowledge of partners, and internal communication. Coordination is defined as a general use structure to bring together groups that are working on general results. Relational skills are skills that cover certain aspects such as the ability to communicate, openness, the capacity to deal with conflict, empathy, emotional stability, self reflection, a sense of justice and cooperation. Whereas partner knowledge describes structured and organized information about suppliers, customers and competitors and enables reduction of transaction costs and management's proactive attitude in resolving conflicts. Finally, Internal Communication includes assimilation and dissemination of information about partners to all departments involved.

Farrell (2000) revealed that products innovation have three indicators, namely: launching a line product that is still familiar to business organizations but new to the market, such as by adding new variants to their products that are done to compare the target market. Then, the imitation product which is a product that is considered new by the business but is familiar with the market that this process is determined by the attitude of accepting and admiring what is imitated. And the last is new products while these products represent new products both by business and the market. Farrell (2000) defines performance as the level of achievement of a business in a given period, where performance is related to business development, new product success, sales growth, return on investment and overall performance. Indicators of performance in this study are sales growth. Sales growth reflects the ability of a business from time to time. The higher the level of sales growth of a business, it mean that the business successfully runs its strategy.

Entrepreneurial orientation describes the extent to which a business can identify and take advantage of market opportunities in order to develop business strategies. Small and micro enterprises owners who have proactive behavior will take advantage of opportunities by constantly looking for customer needs. Then, entrepreneurs provide feedback by creating products that are in line with market demand. Solano, et. al., (2018) revealed that a strong entrepreneurial orientation will 
show a business culture that can facilitate and identify business opportunities that arise, so it is possible for a business to develop new products and services. Furthermore, Ripollés \& Blesa (2016) found that entrepreneurial orientation has a positive effect on market orientation, where a business that has an entrepreneurial orientation is able to recognize market opportunities before its competitors, so they get a lot of market share and benefit. The entrepreneurial orientation will improve market orientation, where a business that has a proactive orientation will develop the best product or market strategy based on opportunities that arise. That way, they can decide how to get market opportunities, which markets are targeted by the business, and how to maintain market share (Morris, et al., 2010). Furthermore, risk taking involves brave behavior on a project that has a higher failure rate (Ripollés \& Blesa, 2016). A business that has a high risk-taking orientation will have a strong commitment to take business projects, use comprehensive actions, take advantage of emerging business opportunities to achieve business goals, meet market needs, and provide customer satisfaction.

\section{H1. entrepreneurial orientation has a significant positive effect on market orientation}

A business that has a strong entrepreneurial orientation will try to get more information, so it is easier to identify business opportunities. To get information, a business will collaborate with partners to make it easier to get information, both from suppliers, entrepreneurs, and other businesses, so it is easier to identify market opportunities (Ripollés \& Blesa, 2016). Then, Mu, et. al., (2016) revealed that entrepreneurial orientation is very important to help a business to be more responsive to market opportunities and costumer needs. However, even though a business has ideas, knowledge and competencies to run a business, they also need complementary resources to produce and deliver goods or services by cooperating with business partners ( $\mathrm{Mu}, 2014)$. Business partners make it easy to access important resources for new combinations of productivity factors, such as developing routines, competencies, and new technologies (Mu \& Benedetto, 2012). Solano, et. al., (2018) revealed the ability of small and medium business networks is very important to build and manage relationships with partners that enable them to gain a very important competitive advantage, especially in small and medium enterprises. Solano, et. al., (2018) revealed that business network ability combined with entrepreneurial orientation will get more market information, so it is easy to identify and take advantage of opportunities. The same thing is explained by Weerawardena, et. al., (2007) that entrepreneurial orientation has a positive effect on business network ability, because of the ability to create and manage networks in higher markets if the business is innovative and proactive, because a business will develop a new thing related to business activities to create a product.

\section{H2. Entrepreneurial orientation has a positive significant effect on business network ability}

Entrepreneurial orientation is defined as the strategic attitude of a business to engage in risk taking and proactive behavior. A business that has an entrepreneurial orientation will be able to see the opportunities and challenges of business in the future, so that a business will make efforts to improve their competitive position. One of the efforts to increase competitive advantage is to create new products. Hoskisson, et. al., (2011) defines entrepreneurial orientation as the enthusiasm of entrepreneurs to take a risks in developing new products, ideas, methods and processes, and become more proactive in identifying and exploiting untapped market opportunities before competitors enter in the same business environment.

Avlonitis \& Salavou (2007) revealed that proactive orientation and risk taking from an active entrepreneur will influence product innovation, namely by displaying product characteristics that are more unique to the market and leading to higher performance. In line with Forkmann, et. al., (2018) revealed that entrepreneurial orientation significantly influences on success in producing new products. Businesses with a high entrepreneurial orientation will improve new products or use new processes to produce products, and actively looking for new knowledge (Genc, et. al., 2019) 


\section{H3. Entrepreneurial orientation has a positive significant effect on product innovation}

Selmi \& Chaney (2018) revealed that market orientation aims are to give customer needs now and in the future. In line with Slater \& Narve (2000) market orientation is the most effective and efficient organizational culture in creating behaviors needed to create superior value for customer, so it will continue to improve business performance. Market orientation is a business strategy to create what customer needs and desires by continuing to assess the needs and desires of customer both now and in the future so market oriented businesses will make customers as the main priority in running their business.

Rodríguez pinto, et. al., (2011) revealed that market orientation influences a business to produce superior new products. A market oriented business will continue to look and identify customer needs and desires. Various components of market orientation, such as customer orientation, competitor orientation have been proposed to better assess how a business collects and distributes important market information, for example related to customer trends and preferences in choosing products, developing consumer trends, and information about business strategies used by competitors and competitor's products, so a business can anticipate competitor actions who can be dangerous to survival of a business. Furthermore, Shihping \& Yu Lin 2011 find market orientation will influence product innovation, where a market oriented business will identify the needs and desires of consumers and create products according to market demand continiously. A market oriented business will know its environment, competitors activities and developing needs from consumers so that a business will continue to innovate on their products and be able to provide better services. Adam (2019) revealed that customer orientation has an effect on innovation, where a customeroriented business will make efforts to create new products according to demand and provide superior value to customers. Liu \& Atuahene (2018) reveal that a customer oriented business takes a proactive approach to continually identifying and meeting customer demand and making feedback by creating products in accordance with demand in a timely manner from customers and adapting to market changes effectively. With a better knowledge of what customers want, customers of a business will make their new products more attractive and different, it is difficult for imitators to produce. this will create satisfaction for customers and build customer loyalty to continue buying the products produced.

\section{H4. Market orientation has a positive significant effect on product innovation}

A market oriented business will continue to get information related to the needs and desires of customers and competitor actions. In a changing market environment, a market oriented business will meet customer needs in a timely manner. Entreprenurs will do efforts to meet customer needs for a product. In line with Vega vázquez (2016)revealed that market orientation will affect the performance of a business. In the face of a highly competitive environment, a market oriented business will have a strong understanding of competitors, where a business will continue to look for information related to competitors activities, both in terms of how their strategies are in marketing products and knowing information about their superior products, so a business can anticipate the competitors actions by making the right strategies in the face of competition.

Smirnova, et. al., (2011) revealed market orientation has a positive effect on industrial performance in Russia, where a market oriented business will provide services to its customers by providing greater value than competitors, conducting differentiation strategies to achieve good performance. Boso, et. al., (2013) stated that market orientation has a positive effect on sales performance and profits in entrepreneurial businesses operating in developing countries. Nakos, et. al., (2018) revealed that orientation towards customers will have a high focus on customers, always strive to increase knowledge to find what is important for their customers and place the interests of customers above all else. They continue to try to understand their customers, to measure customer satisfaction, and provide superior service so customers feel fulfilled their needs and desires and get satisfaction so a business will get the trust of customers and can get sales profits to improve business performance. A business that is competitively oriented has a knowledge of the advantages and disadvantages of the 
main competitors in the market. Wilson (2014) revealed that knowledge of competitors will help a businesses to effectively anticipate and respond to competitors action in the future.

\section{H5. Market orientation has a positive significant effect on performance}

Walter, et. al., (2006) revealed business network ability is the ability of businesses to develop and utilize relationships between organizations to gain access to various resources owned by other actors. Musteen \& Butts (2013) revealed that the ability to establish partners is a very important factor for the success of a business in running business, because business networks ability can overcome the limited of human resources, such as in small and micro businesses that tend to lack important resources, competencies, and knowledge to produce innovation output. Therefore, building a business network is important because it is the main strategy for gaining access to resources, protect themselves from uncertainties and obstacles in the field of operations. Lack of important resources is one of the factor of small and micro businesses often unable to innovate on their own.

Raposo, et. al., (2014) revealed that partner cooperation has a positive influence on the level of innovation, where business networks can overcome the lack of resources owned by a business. This applies to small and micro food that often lack important resources that allow them difficulties in creating ideas for innovation. A business that has strong business networking activities will have good knowledge because it is often interacts, communicates, and coordinates with partners so it can learn the partner's business excellence strategy in marketing new products or producing superior product of the partners. Mu (2014) also revealed the business network abilitys enabled a businesses to gain access to network resources that are important for enhancing product innovation (Mu \& Benedetto, 2012) Collaboration with various external actors, such as suppliers, customers, competitors, and research organizations, for example universities or government laboratories will increase knowledge, so the knowledge gained will be as the basic capital to improve the product innovation ability of a business (Clauss \& Kesting, 2016). Research result of Eggers, et. al., (2018) reveals collaboration with suppliers, clients and research institutions has a positive effect on the extent of product innovation. Eggers, et. al., (2018) also reveals that network activities between businesses and stakeholders have an important impact on the success of innovation, especially for small and medium enterprises that often experiencing lack of important resources that enable them to innovate.

\section{H6. Business network ability have a positive significant influence on product innovation}

Gunn \& Clausen (2013) reveals product innovation as the introduction of a new product, both product renewal in the business or new to the market of a business. whereas According to (Danneels, 2011) Product innovation is the main strategy for businesses to produce sustainable competitive advantages. A business has a goal to maximize profits, therefore it is necessary to maintain the its products in order to remain attractive to the public. For this reason, bisnis actors must innovate their products, so their business can continue to grow. Rosenbusch, et. al., (2011) reveal that innovation can create value for a small and medium business. Then, Eggers, et. al., (2018) revealed that innovation contributes to survival not only for individuals but also for the organization as a whole.

Rhee, et. al., (2010) revealed that innovation affected the performance of small and medium enterprises in South Korea. In line with the findings of Sok, et. al., (2013) innovation has a significant positive effect on performance of small and medium enterprises. Cesar, et. al., (2016) revealed that product innovation has a positive effect on performance of a business. So, it can be concluded, product innovation is one of the important strategies for a business to gain success through the creation of new products by analyzing customer needs that aim to satisfy customers and maintain the continuity of a product so customers remain in demand. because, the key to product success is that the product is able to adapt to the changes that have taken place. Innovating businesses are able to distinguish their own business from competitors, increase market share and increase competitiveness González fernández \& González velasco (2018). Innovation will also create products with higher 
added value. Gomes \& Wojahn (2017) state that businesses that always innovate will respond quickly to environmental pressures, so they have superior performance

\section{H7. Product innovation has a positive influence on business performance}

Based on the problems described above and the gap from the results of previous studies, the researcher is therefore interested in conducting research with the title "The Influence of entrepreneurial orientation, Market Orientation, Business network ability, and Product Innovation on the Performance of Small and micro enterprises Of Food in Padang City".

\section{Methods}

The type of research used in this study is associative descriptive research. This research was conducted in Padang City in 2019. The sampling technique in this study was purposive sampling as many as 195 respondents. The research instrument used was the questionnaire given to the respondents. The measurement used to measure the respondent's response is to use a likert scale with a scale range of $5=$ "Strongly Agree (SS) to 1 "Strongly Disagree (STS)". Data analysis techniques used descriptive analysis and inductive analysis using Structural Equation Modeling (SEM) analysis tools with smart PLS 3.0. This research evaluates the outer model and evaluation inner model before testing the hypothesis. Evaluation of the outer model is done by using validity and reliability tests to obtain representative data which will further analyzed. In testing the validity uses convergent validityand discriminant validity. Then, reliability is tested by using composite reliability. Evaluation is inner model done to test goodness of fit using predictive-relevance (R-Square).

Table 2 Research Variables

\begin{tabular}{|c|c|c|}
\hline Variable & Indicators & Source of \\
\hline $\begin{array}{l}\text { Entrepreneurial } \\
\text { Orientation }\end{array}$ & $\begin{array}{l}\text { Risk-taking } \\
\text { I have a strong proclivity for high risk projects with chances of } \\
\text { very high } \\
\text { returns. } \\
\text { I believes that bold, wide-ranging acts are necessary to achieve the } \\
\text { firm's } \\
\text { objectives. } \\
\text { When confronted with decision-making situations involving } \\
\text { uncertainty, I adopts a bold, aggressive posture in order to } \\
\text { maximize the probability of exploiting potential } \\
\text { opportunities } \\
\text { Proactive } \\
\text { In dealing with its competitors, my business typically initiates } \\
\text { actions which competitors then respond to. } \\
\text { In dealing with its competitors, my business is very often the first } \\
\text { business to introduce } \\
\text { new products/services, administrative techniques, operating } \\
\text { technologies. } \\
\text { In dealing with its competitors, our company typically adopts a }\end{array}$ & $\begin{array}{l}\text { Rhee, et. } \\
\text { al., (2010) }\end{array}$ \\
\hline $\begin{array}{l}\text { Market } \\
\text { Orientation }\end{array}$ & $\begin{array}{l}\text { Customer Orientation } \\
\text { My business pays attention to after-sales services } \\
\text { The purpose of my business is to give satisfaction to consumers. } \\
\text { The competitive advantage in my business is based on } \\
\text { understanding customer needs } \\
\text { In the business that I run, I routinely monitor and assess the level } \\
\text { of commitment in serving customer needs. }\end{array}$ & $\begin{array}{l}\text { Rhee, et. } \\
\text { al., (2010) }\end{array}$ \\
\hline
\end{tabular}


The business strategy that I use is driven by confidence to create value for customers.

\section{Competitor orientation}

My business sales force shares information about competitors (for example, business strategies used by competitors and competitive business advantages)

I respond quickly to the actions of competitors

In business, I regularly discuss the strengths and weaknesses of competitors

I focus on customers who have opportunities for competitive advantage.

\begin{tabular}{|c|c|c|}
\hline $\begin{array}{l}\text { Business network } \\
\text { ability }\end{array}$ & $\begin{array}{l}\text { Coordination } \\
\text { In business, I discuss what I would like and wish to achieve with } \\
\text { each partner. } \\
\text { In business, I adjust the use of resources, such as employees and } \\
\text { finance for each relation with partners. } \\
\text { In business, I learn the goals, performance and strategies of my } \\
\text { partners. } \\
\text { In business, I conduct early evaluation of partners in order to plan } \\
\text { for the building of relations } \\
\text { In business, I designate coordinator whom will be responsible for } \\
\text { te relation with our partners. } \\
\text { In business, I regularly discuss the ways to support each other's } \\
\text { success with partners. } \\
\text { Relationship Skills } \\
\text { I have ability to build good personal relations with partners } \\
\text { In business, I'm able to step on our partner shoes } \\
\text { In business, I often solve problems with our partners in a } \\
\text { constructive way } \\
\text { Partner knowledge } \\
\text { I know the markets of our partners } \\
\text { I know the products/processes/services of our partners } \\
\text { I know the capabilities and strategies of our competitors } \\
\text { Internal communication } \\
\text { In business, employees develop informal contacts among } \\
\text { themselves } \\
\text { In business, communication is regularly made through projects } \\
\text { In business, owners and employees use systemic feedback }\end{array}$ & $\begin{array}{l}\text { Solano, } \\
\text { et. al., } \\
(2018)\end{array}$ \\
\hline $\begin{array}{l}\text { Product } \\
\text { Innovation }\end{array}$ & $\begin{array}{l}\text { Product expansion } \\
\text { I try to add variety to the product that is produced } \\
\text { I make improvements to products that are produced from time to } \\
\text { time } \\
\text { I try to develop products that are a mainstay for the busines } \\
\text { Product imitation } \\
\text { I try to make products resemble competitor products that are } \\
\text { being sold on the market } \\
\text { I am able to increase sales of product imitations that are created } \\
\text { I get a good response from customers about the product imitation } \\
\text { that were created } \\
\text { I created products that are in line with the times }\end{array}$ & $\begin{array}{l}\text { Ferrel } \\
(2000)\end{array}$ \\
\hline
\end{tabular}


Table Cont...

I created a product that a competitor had never made

I created new products with distinctive features from those on the market

Performance Sale Growth since three year

Rhee, et.

al., (2010)

\section{Results and Discussion}

Evaluation Outer models

Evaluation outermodels made to test the validity and reliability of data. Validity test consist of convergent validity, discriminant validity, while reliability is tested using statistical composite reliability. Convergent Validity.

There is an indicator that meet the convergent validity if it has a value factor loading above of 0,6 . The following is the result of convergent validity for entrepreneurial orientation, market orientation, business network ability, product innovation, and performance. Results of convergent validity can be seen in table 3.

Table 3 Convergent Validity

\begin{tabular}{|c|c|c|c|}
\hline Variable & Indicator & $\begin{array}{l}\text { Loading } \\
\text { Factor }\end{array}$ & Specification \\
\hline \multirow{9}{*}{ Product Innovation } & PI1 & 0.783 & Valid \\
\hline & PI2 & 0.776 & Valid \\
\hline & PI3 & 0.803 & Valid \\
\hline & PI4 & 0.673 & Valid \\
\hline & PI5 & 0.658 & Valid \\
\hline & PI6 & 0.712 & Valid \\
\hline & PI7 & 0.735 & Valid \\
\hline & PI8 & 0.734 & Valid \\
\hline & PI9 & 0.661 & Valid \\
\hline \multirow{11}{*}{$\begin{array}{l}\text { Business Network } \\
\text { Ability }\end{array}$} & BNA1 & 0.809 & Valid \\
\hline & BNA2 & 0.825 & Valid \\
\hline & BNA3 & 0.715 & Valid \\
\hline & BNA4 & 0.767 & Valid \\
\hline & BNA5 & 0.830 & Valid \\
\hline & BNA6 & 0.805 & Valid \\
\hline & BNA7 & 0.795 & Valid \\
\hline & BNA8 & 0.720 & Valid \\
\hline & BNA9 & 0.712 & Valid \\
\hline & BNA10 & 0.734 & Valid \\
\hline & BNA15 & 0.751 & Valid \\
\hline \multirow{6}{*}{$\begin{array}{l}\text { Entrepreneurial } \\
\text { Orientation }\end{array}$} & EO1 & 0.790 & Valid \\
\hline & $\mathrm{EO} 2$ & 0.791 & Valid \\
\hline & EO3 & 0.762 & Valid \\
\hline & EO4 & 0.795 & Valid \\
\hline & EO5 & 0.710 & Valid \\
\hline & EO6 & 0.706 & Valid \\
\hline \multirow{4}{*}{ Market Orientation } & MO1 & 0.760 & Valid \\
\hline & $\mathrm{MO} 2$ & 0.750 & Valid \\
\hline & MO3 & 0.756 & Valid \\
\hline & $\mathrm{MO} 4$ & 0.793 & Valid \\
\hline
\end{tabular}


Table Cont...

\begin{tabular}{cccc}
\hline & MO5 & 0.769 & Valid \\
\cline { 2 - 4 } & MO6 & 0.749 & Valid \\
\cline { 2 - 4 } & MO7 & 0.722 & Valid \\
\cline { 2 - 4 } & MO8 & 0.769 & Valid \\
\cline { 2 - 4 } & MO9 & 0.759 & Valid \\
\hline Performance & SG & 1.000 & Valid \\
\hline
\end{tabular}

Table 3 shows the value of outer loading of each indicator. Based on the results of the analysis, it can be stated that each indicator has convergent validity because each indicator has met the requirements of the value of outer loading $>0.60$.

\section{Discriminant Validity}

Discriminant validity can be seen from the average variance extracted. Construction with good validity require AVE values above 0.50 . The result of discriminant validity can be seen on table 4 .

Table 4 Average Variance Extracted (AVE)

\begin{tabular}{lcc}
\hline \multicolumn{1}{c}{ Variable } & $\begin{array}{c}\text { Average Variance } \\
\text { Extracted (AVE) }\end{array}$ & Specification \\
\hline Product Innovation & 0.530 & Valid \\
\hline Businesss Performance & 1.000 & Valid \\
\hline Business Network Ability & 0.594 & Valid \\
\hline Entrepreneurial Orientation & 0.578 & Valid \\
\hline Market Orientation & 0.576 & Valid \\
\hline Source: 2019 Primary Data (Processed) & &
\end{tabular}

Base on Table. 4, it can be seen the AVE value of all variables, fulfilling the rule of thumb required, with the AVE value must be greater than 0.50 (AVE> 0.50). Business performance variables reach a value of 1.000. Product innovation variables reach a value of 0.530 . Business network ability variable reaches a value of 0.594 . Entrepreneurial orientation variable reaches a value of 0.578 . The market orientation variable reaches a value of 0.576 .

Reliability test

In this reliability test there is composite reliability tables that must be observed. The value of composite reliability above 0.7 is the expected value. The result of the reliability test are shown in table 5

Table 5 Value of Composite Reliability

\begin{tabular}{lcc}
\hline \multicolumn{1}{c}{ Variable } & Factor Loading & Specification \\
\hline Product Innovation & 0.910 & Reliable \\
\hline Businesss Performance & 1.000 & Reliable \\
\hline Business Network Ability & 0.941 & Reliable \\
\hline Entrepreneurial Orientation & 0.891 & Reliable \\
\hline Market Orientation & 0.908 & Reliable \\
\hline
\end{tabular}

Based on table 5, it can be seen that the value of composite reliability of the fifth variable value are above 0.7, thus it can be conclude that all of variable namely product innovation, business performance, business network ability, entrepreneurial orientation, and market orientation have been reliable.

\section{Evaluation of Inner Model}

Testing goodness of fit models structural in the inner model using model predictive-relevance (QSquare). The value of R-square from each endogenus variables can be seen in table 6 
Table 6 R-Square

\begin{tabular}{cc}
\hline Endogenous Variable & Value R-square \\
\hline Product Innovation & 0.177 \\
\hline Performance & 0.055 \\
\hline Business network ability & 0.361 \\
\hline Market Orientation & 0.392 \\
\hline
\end{tabular}

Based on table 6, the value of R-Square for product innovation is 0.177 . it is mean that the percentage of product innovation can be explained by entrepreneurial orientation, market orientation, business network ability are $17.7 \%$. The R-square value for performance is 0.055 . it is mean that the percentage of performance can be explained by market orientation, entrepreneurial orientation and product innovation are $5.5 \%$. The R-square value for business network ability is 0.361 . it is mean that the percentage of business network ability can be explained by entrepreneurial orientation is $36.1 \%$. the R-square value for market orientation is 0.392. it is mean that percentage for market orientation can be explained by entrepreneurial orientation is $39.2 \%$. The assessment of goodness of fit is known by looking Q-value square. The Q-square value has the same meaning as the coefficient of determination (R-square) in regression analysis. The results of calculating $\mathrm{Q}$-value square are following:

Q-square $=1-[(1-0.177)] \times(1-0.055)] \times(1-0.361)] \times(1-0.392)]$

$$
\begin{aligned}
& =1-[0.823 \times 0.945 \times 0.639 \times 0.608] \\
& =1-0.302 \\
& =0.697
\end{aligned}
$$

From the calculation results, the value Q-square has obtained greater than 0 (0.697), so it can be interpreted that the model is good because it has a relevant predictive value of $69.7 \%$. that is the magnitude of the diversity of research data that can be explained by the research model is $69.7 \%$, while the remaining $30.2 \%$ is explained by other factors outside to the model. Based on these results, the research model has good goodness of fit

\section{Hypothesis Test}

This study uses structural equations using the approach Partial Least Square (PLS). The test results of this research model can be seen in figure 1

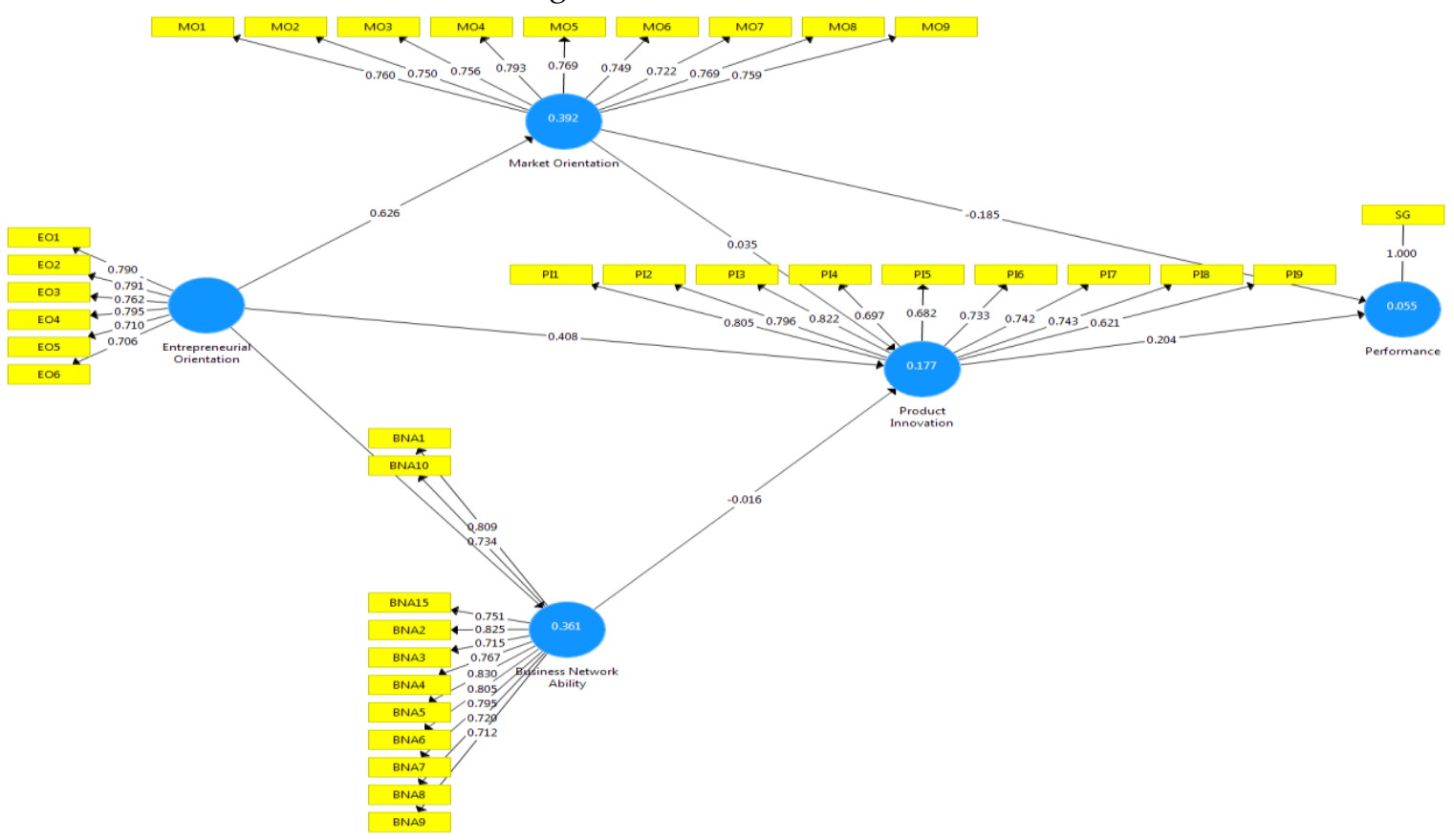

Figure 1 Sub Structure 
Results test with Partial Least Square show that all indicators are above 0.6, so this modeling is feasible to test hypothesis. Hypothesis testing is used by looking T-statistic and P-values. The research hypothesis can be accepted if T-statistic $>1.96$ and P-values $<0.05$. The influence coefficients, T-statistic and P-values can be seen on table 7.

Table 7 Results of coefficient values, T-statistic and P-values

\begin{tabular}{|c|c|c|c|c|c|}
\hline Hypotheses & Relationship Effect & Coefficients & $\begin{array}{c}\text { T- } \\
\text { statistics }\end{array}$ & Description & P-values \\
\hline H1 & $\begin{array}{l}\text { Entrepreneurial } \\
\text { Orientation -> Market } \\
\text { Orientation }\end{array}$ & 0.626 & 9.742 & $\begin{array}{l}\text { Significant, } \\
\text { Hypothesis } \\
\text { supported }\end{array}$ & 0.000 \\
\hline $\mathrm{H} 2$ & $\begin{array}{l}\text { Entrepreneurial } \\
\text { Orientation -> } \\
\text { Business Network } \\
\text { Ability }\end{array}$ & 0.601 & 10.087 & $\begin{array}{l}\text { Significant, } \\
\text { Hypothesis } \\
\text { supported }\end{array}$ & 0.000 \\
\hline $\mathrm{H} 3$ & $\begin{array}{l}\text { Entrepreneurial } \\
\text { Orientation -> Product } \\
\text { Innovation }\end{array}$ & 0.408 & 3.398 & $\begin{array}{l}\text { Significant, } \\
\text { Hypothesis } \\
\text { supported }\end{array}$ & 0.001 \\
\hline $\mathrm{H} 4$ & $\begin{array}{l}\text { Market Orientation -> } \\
\text { Product Innovation }\end{array}$ & 0.035 & 0.231 & $\begin{array}{l}\text { Insignificant, } \\
\text { Hypothesis not } \\
\text { supported }\end{array}$ & 0.817 \\
\hline H5 & $\begin{array}{l}\text { Market Orientation -> } \\
\text { Performance }\end{array}$ & 0.185 & 2.243 & $\begin{array}{l}\text { Significant, } \\
\text { Hypothesis } \\
\text { supported }\end{array}$ & 0.025 \\
\hline H6 & $\begin{array}{l}\text { Business Network } \\
\text { Ability -> Product } \\
\text { Innovation }\end{array}$ & -0.016 & 0.150 & $\begin{array}{l}\text { Insignificant, } \\
\text { Hypothesis not } \\
\text { supported }\end{array}$ & 0.881 \\
\hline H7 & $\begin{array}{l}\text { Product Innovation -> } \\
\text { Performance }\end{array}$ & 0.204 & 2.484 & $\begin{array}{l}\text { Significant, } \\
\text { Hypothesis } \\
\text { supported }\end{array}$ & 0.013 \\
\hline
\end{tabular}

Furthermore, direct and indirect influences in this study can be seen in table 8

Table 8 Direct and Indirect

\begin{tabular}{|c|c|c|c|c|}
\hline Variables & $\begin{array}{l}\text { Direct Effect } \\
\text { Significance }\end{array}$ & $\begin{array}{c}\mathrm{T}- \\
\text { statistics }\end{array}$ & Indirect Sifnificant & P-values \\
\hline $\begin{array}{l}\text { Entrepreneurial } \\
\text { Orientation -> } \\
\text { Market Orientation }\end{array}$ & $\begin{array}{r}0.626 \\
\text { (Significant } \\
\text { T-statistic } \\
>1.96 \text { and } \mathrm{P}- \\
\text { values }<0.05 \text { ) }\end{array}$ & 9.742 & - & 0.000 \\
\hline $\begin{array}{l}\text { Entrepreneurial } \\
\text { Orientation -> } \\
\text { Business Network } \\
\text { Ability }\end{array}$ & $\begin{array}{r}0.601 \\
\text { (Significant } \\
\text { T-statistic } \\
>1.96 \text { and P- } \\
\text { values }<0.05 \text { ) } \\
\end{array}$ & 10.087 & - & 0.000 \\
\hline $\begin{array}{l}\text { Entrepreneurial } \\
\text { Orientation -> } \\
\text { Product Innovation } \\
\text { Throught market } \\
\text { orientation }\end{array}$ & $\begin{array}{r}0.408 \\
\text { (Significant } \\
\text { T-statistic } \\
>1.96 \text { and P- } \\
\text { values }<0.05\end{array}$ & 3.398 & $\begin{array}{c}(0.408 \times 0.231)=0.04 \\
\text { [insignificant, T- } \\
\text { statistic }<1.96 \\
(0.226<1.96) \text { and } \mathrm{P}- \\
\text { value }>0.05 \\
0.821>0.05\end{array}$ & 0.001 \\
\hline
\end{tabular}


Table Cont...

\begin{tabular}{|c|c|c|c|c|}
\hline $\begin{array}{l}\text { Market Orientation } \\
\text {-> Product } \\
\text { Innovation }\end{array}$ & $\begin{array}{r}0.035 \\
\text { (Insignificant } \\
\text { T-statistic } \\
<1.96 \text { and } \mathrm{P}- \\
\text { values }>0.05\end{array}$ & 0.231 & - & 0.817 \\
\hline $\begin{array}{l}\text { Market Orientation } \\
\text {-> Performance } \\
\text { through product } \\
\text { innovation }\end{array}$ & $\begin{array}{r}0.185 \\
\text { (Significant } \\
\text { T-statistic } \\
>1.96 \text { and } \mathrm{P}- \\
\text { values }<0.05\end{array}$ & 2.243 & $\begin{array}{c}(0.185 \times 0.035)=0.006 \\
\text { [insignificant, } \mathrm{T}- \\
\text { statistic }<1.96 \\
(0.214<1.96) \text { and } \mathrm{P}- \\
\text { value }>0.05 \\
0.831>0.05\end{array}$ & 0.025 \\
\hline $\begin{array}{l}\text { Business Network } \\
\text { Ability -> Product } \\
\text { Innovation }\end{array}$ & $\begin{array}{r}-0.016 \\
\text { (Insignificant } \\
\text { T-statistic } \\
<1.96 \text { and } \mathrm{P}- \\
\text { values }>0.05\end{array}$ & 0.150 & - & 0.881 \\
\hline $\begin{array}{l}\text { Product Innovation } \\
\text {-> Performance }\end{array}$ & $\begin{array}{r}0.204 \\
\text { (Significant } \\
\text { T-statistic } \\
>1.96 \text { and } \mathrm{P}- \\
\text { values }<0.05\end{array}$ & 2.484 & - & 0.013 \\
\hline
\end{tabular}

Based on the results of testing the hypothesis 1, it was found that there was a positive and significant effect of entrepreneurial orientation on market orientation in small and micro enterprise of food in Padang City. The results of this study indicate that the higher the behavior of entrepreneurial orientation such as risk taking and proactivity, the more the market orientation of small and micro enterprise of food from an entrepreneurs in Padang city. Small and micro enterprises of food who have a proactive attitude will continue to take advantage of opportunities by continuing to look for market needs and desires and provide feedback by creating products that are in line with market demand. Then, the entrepreneurs who have a proactive attitude will develop the product or use the right market strategy in accordance with the business opportunities that arise. Furthermore, Risk taking involves brave action to take a project that has a higher failure rate. The ability of entrepreneurial orientation is needed by small and micro enterprises to carry out market orientation activities, so the courage in taking a risks and taking a business opportunity will facilitate small and micro food enterprises in Padang city to get market knowledge, so it can increase attention to meet their needs and market desires and provide satisfaction for customer.

The results of this study are in line with previous research conducted by Vega, et. al., (2016) that entrepreneurial orientation will influence market orientation, where entrepreneurial orientation will help an entrepreneur to recognize market opportunities. The same thing was found by (Ripollés \& Blesa, 2016) that entrepreneurial orientation has a positive effect on market orientation, where a business that has an entrepreneurial orientation will be able to understand and recognize market opportunities before competitors so that they gain more market share and benefit. In line with previous research conducted by Solano, et. al., (2018) that stated a proactive orientation can create a competitive advantage by becoming the first mover in business before competitors enter the market, so a business can obtain market resources and increase competitiveness.

Based on the results of testing the hypothesis 2 , it was found that there was a significant effect of entrepreneurial orientation on the business network abilitys on small and micro enterprises of food in Padang city. The results of this study indicate that good entrepreneurial orientation such as risk taking and proactive will increase capacity of the business network ability of small and micro entrepreneur. This research proves that the implementation of a good entrepreneurial orientation will 
be able to improve the ability of small and micro enterprises of food in Padang City. This means that small and micro enterprises that have a proactive and risk taking attitude will see more market information by partnering with other business resources, such as suppliers of raw materials, similar businesses, business cooperatives. If this is done by entrepreneur, so a business is able to identify and utilize business opportunities faster than competitors. Small and micro enterprises of food that have an entrepreneurial orientation will have human resources who have risk taking behavior and proactive, so it will help businesses to be more responsive in utilizing every business opportunity and using a comprehensive business strategy to achieve business goals. To take greater business opportunities, small and micro enterprises of food will establish partnerships to overcome the low capacity of human resources or to complete complementary resources in producing superior products and delivering goods or services.

The results of this study are in line with previous studies conducted by Solano, et. al., (2018) which states that business network activities combined with entrepreneurial orientation will get more market information so, it is easy to identify and take advantage of opportunities. In line with the findings of Weerawardena et. al., (2007) entrepreneurial orientation has a positive effect on the business network abilitys, because of the ability to create and manage networks in higher markets if the business is innovative and proactive, because a business will develop a new thing related to business activities in generating a product.

Based on the results of testing the hypothesis 3, it was found that there was a positive and significant effect of entrepreneurial orientation on product innovation in small and micro of food in Padang city. The results of this study indicate that the higher the behavior of entrepreneurial orientation such as risk taking and proactivity, it will increase product innovation from small and micro entrepreneur of food in Padang city. This research proves that the implementation of a good entrepreneurial orientation will increase the ability to carry out product innovation for small and micro enterprises of food in Padang city. Furthermore, small and micro enterprises of food in Padang City that have a risk taking attitude will have a high attitude of enthusiasm to develop their products, such as creating more unique products. then, imitating superior products from competitors, so entrepreneur can increase competitive advantage. then, entrepreneur who have a proactive attitude will be able to create new products in accordance with the business opportunities that arise, create new business opportunities, and be brave to take a risks in making uncertain decisions but provide opportunities for better results. Then, small and micro entrepreneur who have entrepreneurial orientation will be proactive and brave enough to take risks, making small and micro entrepreneur of food have the ability to create innovative products that precede their competitors, so they are able to satisfy customers and provide superior value because they always innovate products.

The results of this study are in line with previous research conducted by Stephen, et. al., (2018) that entrepreneurial orientation significantly influences the success of an entrepreneur in creating a new product, where a business with a high entrepreneurial orientation will improve new products and use new processes to produce products and actively find new knowledge to develop products produced . In line with Gen's findings (2017) which reveal that entrepreneurial orientation influences product innovation, where a business actor always has a proactive attitude will take the opportunity that arise by observing market needs and desires. That way it will help small and micro entrepreneur of food in creating new products in accordance with market demand.

Based on the results of testing the hypothesis 4, there was no effect of market orientation on product innovation in small and micro enterprises of food processing in Padang city. The results of this study contrast with the results of previous studies. The results of this study are in line with Tajeddini \& Trueman (2008) and (Tajeddini, 2011) research which found that market orientation did not affect product innovation. Based on the results of testing the hypothesis, there was no effect of market orientation on product innovation in small and micro enterprises of food in padang city. The results of this study are supported by the argument made by Makoto (2006) who notes that customer orientation and innovation have conflicting goals, where innovation and customers build relationships that have economic, cultural, and competitive necessity. Therefore, pursuing excellence 
in both is not possible. They further argue that innovation requires an employee centric perspective, while customer orientation emphasizes the customer. This is in line with the opinion of Tajeddini (2011) which states that owners of small and medium businesses prioritize the interests of customers to develop profitable long term companies.

Research contrasts with previous studies, such as the research of Rodríguez Pinto, et, al., (2011), Shihping and Yu Lin (2012), Liu and Atuahene (2018). The difference in results is not only due to differences in the object of research. Indeed, most of the previous research found that there was a significant influence between market orientation on product innovation carried out in medium sized businesses and large businesses in developed countries that clearly had different characteristics from developing countries. Then, for regions in developed countries generally have adopted the concept of good market orientation, so it can improve product innovation.

Based on the results of testing the hypothesis 5, it was found that there was a positive and significant influence of market orientation on performance on small and micro enterprises of food in Padang city. The results of this study indicate that the higher the market orientation such as customer orientation and market orientation, it will improve business performance in small and micro entreprises of food in Padang city. This study proves that the implementation of good market orientation will improve the performance of small and micro enterprises of food in Padang city. Entrepreneur who have market orientation will continue to collect market information related customer needs and desires and information related to competitors, such as any form of competitor's actions. by knowing competitor action, it can be anticipated in order to maintain business continuity. Then, market oriented business actors will meet customer needs in a timely manner. Efforts to meet the needs and desires of market in a timely manner will make the product of a business will continue to be sought after by customers, so it will improve business performance. Market oriented from entrepreneur in Padang City will have a strong understanding of competitors, where a business will continue to look for information related to competitor activities, both in terms of how their strategies are in marketing products and knowing information about their superior products, so a business can anticipate the competitor's actions by making the right strategies in the face of competition. In line with Wilson's opinion (2014) stated knowledge of the ability of competitor will help businesses to effectively anticipate and respond to competitors' movements in the future.

The results of this study are in line with previous research conducted by Smirnova (2011) revealing that market orientation has a positive effect on industrial performance in Russia, where a market oriented business will provide the best service to its customers by providing greater value than competitors. then make a differentiation strategy, so it achieves good performance. Boso, et. al., (2013) stated that market orientation has a positive effect on sales performance and profits in entrepreneurial businesses operating in developing countries. Nakos, et. al., (2018) also revealed that a business that has an orientation attitude towards customers will have a high focus on customers, always strives to increase knowledge to find what is important for their customers and put the interests of customers above all else.

Based on the results of testing the hypothesis 6, the business network abilitys does not affect product innovation in small and micro enterprises in Padang city. The results of this study indicate that the capacity of business networks is done by small and micro entrepreneurs in padang city have not an effect on product innovation. this can happen because the majority of small and micro entrepreneurs still have low levels of education. Musteen and Butts (2013) reveal that small and micro businesses tend have not important resources, competencies, and knowledge to produce innovation output. this can be seen based on the characteristics of small and micro enterprises of food in Padang city, where business people who have elementary education level are 33 people, junior high school education as many as 37 people, high school education as many as $85, \mathrm{~S} 1$ education as many as 10, S2 education as many as 10. From 195 respondents of entrepreneur, it was known that 155 or $79.48 \%$ were not in the undergraduate degree. The low level education of small and micro enterprises of food can make the knowledge of business entrepreneur low, thus that is hampering the ability to manage business, such as generating creative ideas and trying new knowledge to produce new 
products that are more unique than competitors. Another support stated by Octavia and Ali (2017 who explained that human resource factors affect the ability of a business in product innovation. Eggers (2018) also revealed that the low level of knowledge to business actor can hamper the ability of a business actor to innovate.

Based on the results of testing the hypothesis 7 it was found that there was positive and significant effects of product innovation on business performance on small and micro enterprises of food in Padang city. The results of this study indicate that the higher the product innovation, such as product expansion, product imitation, create new products, it will improve business performance in small and micro enterprises of food in padang city. This research proves that the implementation of good product innovation will improve business performance in small and micro enterprises of food in padang city. Small and micro entrepreneur that carry out product innovations will develop their products, for example adding variety of tastes, modifying products and making updates by creating new products in line with current development, so the product will continue to be attractive to the market and will improve business performance.

This is in line with previous research conducted by Baker and Sinkula (2009) which reveals the success in product innovation will increase the performance of a business, where a business that conducts a renewal of its products will create new products in accordance with the times, so the products are always in demand by the market and can increase business profits. Rhee, et. al., (2010) revealed that innovation affected the performance of small and medium enterprises in South Korea. Furthermore, Sok, et. al., (2013) also found that innovation had a significant positive effect on the performance of small and medium enterprises. The same thing was found by Cesar, et. al., (2016) revealed that product innovation has a positive effect on the performance of a business.

\section{Conclusion}

The results of this study show that entrepreneurial orientation has a positive effect on market orientation. Entrepreneurial orientation has a positive effect on business network ability, entrepreneurial orientation has a positive effect on product innovation, market orientation has not positive effect on product innovation, market orientation has a positive effect on performance, business network ability has not positive effect on product innovation. Product innovation has a positive effect on performance.

Practically, this study is expected to increase knowledge of researchers who are also students, as a form of development of thinking in the application of knowledge that has been studied by researchers in college, and to equip mine later in the community related to how to improve performance. This research is also expected to provide additional knowledge for students related to the influence of entrepreneurial orientation, market orientation, business network ability and product innovation on the performance of small and micro enterprises, So students can use it as a provision later to find out how to improve the performance of a business. Then, For entrepreneur, this research can be use to advice entrepreneurs, so they know what are the best strategy can be made in improving their business performance. Furthermore, for other readers or researchers, this research can be use as knowledge that enhance reference sources to further research that discusses the influence of entrepreneurial orientation, market orientation, business network ability and product innovation on small and micro enterprises performance.

\section{References}

Avlonitis, G. J., \& Salavou, H. E. (2007). Entrepreneurial orientation of SMEs, product innovativeness, and performance, 60, 566-575. https://doi.org/10.1016/j.jbusres.2007.01.001

Boso, N., Story, V. M., \& Cadogan, J. W. (2013). Journal of Business Venturing Entrepreneurial orientation, market orientation, network ties, and performance: Study of entrepreneurial fi rms in a developing economy. Journal of Business Venturing, 1-20. https:// doi.org/ 10.1016/j. jbusvent. 2013.04.001

Clauss, T., \& Kesting, T. (2016). Industrial Marketing Management How businesses should govern 
knowledge-intensive collaborations with universities: An empirical investigation of university professors. Industrial Marketing Management. https://doi.org/10.1016/j.indmarman.2016.09.001

Danneels, E. (2011). The dynamics of product innovation and firm competences. Strategic Management Journal, 23, 1095-1121.

Eggers, F., Niemand, T., Filser, M., Kraus, S., \& Berchtold, J. (2018). Technological Forecasting \& Social Change To network or not to network - Is that really the question? The impact of networking intensity and strategic orientations on innovation success. Technological Forecasting $\mathcal{E}$ Social Change, (July), 0-1. https://doi.org/10.1016/j.techfore.2018.09.003

Forkmann, S., Henneberg, S. C., \& Mitrega, M. (2018). Capabilities in business relationships and networks: Research recommendations and directions. Industrial Marketing Management, (xxxx), 1-26. https://doi.org/10.1016/j.indmarman.2018.07.007

Genc, E., Dayan, M., \& Faruk, O. (2019). The impact of SME internationalization on innovation: The mediating role of market and entrepreneurial orientation. Industrial Marketing Management, (January), 0-1. https://doi.org/10.1016/j.indmarman.2019.01.008

Gomes, G., \& Wojahn, R. M. (2017). Organizational learning capability, innovation and performance: study in small and medium-sized enterprises (SMES). Revista de Administração, 52(2), 163-175. https://doi.org/10.1016/j.rausp.2016.12.003

González fernández, M., \& González velasco, C. (2018). Innovation and Corporate Performance in the Spanish Regions. Journal of Policy Modeling. https://doi.org/10.1016/j.jpolmod.2018.05.005

Gunn, W., \& Clausen, C. (2013). Gunn, W and Clausen, C. 2013. Conceptions of innovation and practice: designing indoor climate. In Gunn, W. Otto, T and Smith, R.C (eds),. Design Anthropology: Theory and Practice, 159-179.

Hoskisson, R. E., Covin, J., Volberda, H. W., \& Johnson, R. A. (2011). Revitalizing Entrepreneurship : The Search for New, (September). https://doi.org/10.1111/j.1467-6486.2010.00997.x

Liu, W., \& Atuahene gima, K. (2018). Enhancing product innovation performance in a dysfunctional competitive environment: The roles of competitive strategies and market-based assets. Industrial Marketing Management, (December 2017), 1-14. https://doi.org/10.1016/ j.indmarman. 2018.01.006

Makoto, M. (2006). Customer orientation, conflict, and innovativeness in Japanese sales departments. Journal of Business Research, 59(2), 242-250. https://doi.org/10.1016/j.jbusres.2005.06.002

$\mathrm{Mu}, \mathrm{J}$. (2014). Networking Capability, Network Structure, and New. Iee Transactions On Engineering Management, 61(4), 599-609.

$\mathrm{Mu}$, J., \& Benedetto, A. Di. (2012). Product Development. Iee Transactions On Engineering Management, 59(1), 4-19.

Musteen, M., \& Butts, M. M. (2013). E T \& P, (619), 1-26. https://doi.org/10.1111/etap.12025

Nakos, G., Dimitratos, P., \& Elbanna, S. (2018). The mediating role of alliances in the international market orientation- performance relationship of smes. International Business Review, (December), 1-10. https://doi.org/10.1016/j.ibusrev.2018.12.005

Nur, N., \& Salim, U. (2014). Entrepreneurship Orientation, Market Orientation, Business Strategy , Management Capabilities On Business Performance; Study At Small And Medium Enterprise Printing In Kendari ". International Journal of Business and Management Invention, 3(12), 8-17.

Qiao, P. X. J. H.-G. F. (2014). Industry association networks, innovations, and firm performance in Chinese small and medium-sized enterprises. China Economic Review, 29, 213-228. https://doi.org/10.1016/j.chieco.2014.04.011

Raposo, M. L., Ferreira, J. J. M., \& Fernandes, C. I. (2014). Revista Europea de Dirección y Economía de la Empresa Local and cross-border SME cooperation: Effects on innovation and performance. Revista Europea de Dirección Y Economía de La Empresa, 23(4), 157-165. https ://doi.org/10.1016/j. redee.2014.08.001

Rhee, J., Park, T., \& Hyung, D. (2010). Technovation Drivers of innovativeness and performance for innovative SMEs in South Korea: Mediation of learning orientation. Technovation, 30(1), 65-75. https://doi.org/10.1016/j.technovation.2009.04.008 
Ripollés, M., \& Blesa, A. (2016). Entry mode choices in the international new ventures context . A study from different theoretical perspectives. International Entrepreneurship and Management Journal.

Rodríguez-pinto, J., Carbonell, P., \& Rodríguez-escudero, A. I. (2011). Intern . J . of Research in Marketing Speed or quality? How the order of market entry in fl uences the relationship between market orientation and new product performance. International Journal of Research in Marketing, 28(2), 145-154. https://doi.org/10.1016/j.ijresmar.2011.02.001

Rosenbusch, N., Brinckmann, J., \& Bausch, A. (2011). Journal of Business Venturing Is innovation always bene fi cial? A meta-analysis of the relationship between innovation and performance in SMEs. Journal of Business Venturing, 26(4), 441-457. https://doi.org/10.1016/j.jbusvent.2009.12.002

Selmi, N., \& Chaney, D. (2018). A measure of revenue management orientation and its mediating role in the relationship between market orientation and performance. Journal of Business Research, 89(July 2017), 99-109. https://doi.org/10.1016/j.jbusres.2018.04.008

Shihping Kevin Huanga, Y.-L. W. (2011). Entrepreneurial orientation, learning orientation, and innovation in small and medium enterprises. Journal of Research in Marketing and Entrepreneurship, 8(4), 563-570. https://doi.org/10.1016/j.sbspro.2011.09.004

Slater, S. F., \& Narve, J. C. (2000). The Positive Effect of a Market Orientation on Business Profitability: A Balanced Replication. Journal of Business Research, 48, 69-73.

Smirnova, M., Naudé, P., Henneberg, S. C., Mouzas, S., \& Kouchtch, S. P. (2011). Industrial Marketing Management The impact of market orientation on the development of relational capabilities and performance outcomes: The case of Russian industrial fi rms. Industrial Marketing Management, 40(1), 44-53. https://doi.org/10.1016/j.indmarman.2010.09.009

Sok, P., Cass, A. O., \& Mony, K. (2013). Achieving superior SME performance: Overarching role of marketing, innovation, and learning capabilities. Australasian Marketing Journal, 21(3), 161-167. https://doi.org/10.1016/j.ausmj.2013.04.001

Solano, A., Herrero, A., \& Collado, J. (2018). E ff ect of market orientation, network capability and entrepreneurial orientation on international performance of small and medium enterprises ( SMEs ). International Business Review, (June 2017), 0-1. https: //doi.org/10.1016/j. ibusrev. 2018.04.004

Tajeddini, K. (2011). Customer orientation, learning orientation, and new service development: An empirical investigation of the swiss hotel industry. Journal of Hospitality and Tourism Research, 35(4), 437-468. https://doi.org/10.1177/1096348010380599

Tajeddini, K., \& Trueman, M. (2008). Effect of customer orientation and innovativeness on business performance: a study of small-sized service retailers. International Journal of Entrepreneurship and Small Business, 6(2), 280. https://doi.org/10.1504/ijesb.2008.018633

Vega-vázquez, M. (2016). Entrepreneurial orientation - hotel performance: Has market orientation anything to say?. Journal of Business Research. https://doi.org/10.1016/j.jbusres. 2016.04.085

Walter, A., Auer, M., \& Ritter, T. (2006). The impact of network capabilities and entrepreneurial orientation on university spin-off performance. Journal of Business Venturing 21, 21, 2005-2007. https://doi.org/10.1016/j.jbusvent.2005.02.005

Weerawardena, J., Sullivan, G., Liesch, P. W., \& Knight, G. (2007). Conceptualizing accelerated internationalization in the born global firm: A dynamic capabilities perspective. Journal of World Business, 42, 294-306. https://doi.org/10.1016/j.jwb.2007.04.004

Wilson, G. A. (2014). Market orientation, alliance orientation, and business performance in the biotechnology industry. Journal Of Commercial Biotechnology, 1-10. https://doi.org/10.5912/jcb645 